\title{
Education and training in Romania on occupational safety and health in the offshore industry
}

\author{
Mariana Ratiu $^{1, *}$, Corina Suteu $^{2}$, and Ioan-Florin Oarga ${ }^{3}$ \\ ${ }^{1}$ University of Oradea, Department of Mechanical Engineering and Automotive, 410087 Oradea, Romania \\ ${ }^{2}$ University of Oradea, Department of Psycho-Neurosciences and Rehabilitation, 410073 Oradea, Romania \\ ${ }^{3}$ Technical University of Cluj-Napoca, Faculty of Machine Building, 400641 Cluj-Napoca, Romania
}

\begin{abstract}
This paper is the result of a study on the current situation in Romania regarding education and training on the occupational safety and health in the offshore industry. This study was conducted within a European project, which, among other things, has as intellectual outputs, identifying the main requirements related to learning needs and competencies and identifying the similar safety and health training courses for offshore industry at European level. Romania has transposed the European Union legislation in the area of minimum requirements for the safety and health of workers in the offshore industry and has an adequate institutional framework aligned to the Community requirements in the field. In Romania, there are no special occupations and explicit requirements for occupational safety and health specialists in the offshore industry. But, there are some training centers, which offer theoretical and practical courses regarding safety and health for those graduates or professionals who wish to pursue a professional career in the offshore industry. Also, some universities provide diplomas, courses or training related to the offshore industry.
\end{abstract}

\section{Introduction}

Against the backdrop of increasing energy consumption and the reduction of underground natural resources, the offshore industry has been growing in the last time. However, some serious accidents that were happened in this field and that led to environmental disasters, economic damages, and loss of life, illustrated the need for comprehensive measures in this field.

The "offshore industry" means "off the coast industry" and comprises the offshore oil and gas industry and the offshore renewables and marine energy industry (offshore wind, tidal and wave).

In the offshore industry, there is a wide range of challenging occupations, but which requires many hours of work in tough conditions. The occupations in offshore industry are at all levels, from entry-level to experienced professionals, in different fields: drilling, piping, welding, diving, production, rigging, surveying, as well as in quality, environment, safety and health, and other support staffing. Under the laws and regulations in force, all companies from offshore industry have a great responsibility for their employees and the environment. So all specific requirements regarding safety, health and environment have to be integrated into all offshore activities, including in education and training courses of the employees.

\section{Romanian strategy and legislation related to occupational safety and health}

By now, Romania did have not a strategy on safety and health at national level, adopted by a normative act. During this period, it is in consultation a proposal for the Romanian Occupational Safety and Health Strategy for the period 2017-2020. This strategy represents an opportunity to achieve a safe and healthy work environment and a framework instrument that ensures the correlation with the strategic directions of the European Union on occupational health and safety [1].

In Romania, the field of the occupational safety and health is regulated through three major levels of legislation: primary, secondary and tertiary legislation. The primary legislation is the Law no. 319 of 14 July 2006 on safety and health at work that is mandatory to be applied to all sectors of activity, both public and private, and to employers, workers, and representatives of the workers. According to it, the employers shall ensure such conditions that each worker receives sufficient and adequate safety and health training [2].

The secondary legislation includes preventive measures and rules of application specified in methodological norms for the enforcement of the law no. 319 on safety and health at work [3]; government decisions transposing EU directives; standards (standards on safety, standards of the products).

In the tertiary legislation are detailed preventive measures in different regulations or instructions of the companies, in the completion and implementation of the regulation in the field according to the specific conditions of their activity.

\footnotetext{
* Corresponding author: mratiu@uoradea.ro
} 


\section{Relevant authorities and institutions with attributions in the field}

The Ministry of Labor and Social Justice is the relevant authority in the field of occupational safety and health in Romania, having the main attributions: to elaborate, in cooperation with the Ministry of Health and by consultations with other institutions with attributions in the field, the policy and the national strategy on occupational safety and health; to authorize the persons who perform the services in the field of the protection and prevention; to coordinate, in collaboration with the Ministry of Research and Innovation, the elaboration of the national research programs in the field of occupational safety and health; to organize, together with the Ministry of National Education, the activity of general and/or specific training in the field of occupational safety and health for educational institutions; to approve diverse information and training materials, for a correct information [4].

The Ministry of Health is the responsible central public authority in the field of workers' health at the workplace [5].

The Labor Inspection represents the relevant authority concerning the control of the application of the legislation on safety and health at work [6].

The National Research and Development Institute of Occupational Safety (INCDPM) - "Alexandru Darabont" is a research and development institute accredited by the national authority for scientific research (ANCS) as a Romanian national legal entity of public interest, coordinated by the Ministry of National Education [7].

The National Qualifications Authority (NCA) regulates and coordinates the framework of continuing education and training for adults, develops and manages the National Register of Qualifications and National Register of training providers, coordinates and controls the licensing and authorization process for adult training providers and centres of professional competence assessment and certification of professional competence assessors [8].

\section{Legislation and competencies regarding the safety of the offshore operations}

To help prevent offshore accidents from happening and to ensure the proper response if they do, the EU adopted the Directive 2013/30/EU on Safety of Offshore Oil and Gas Operations. According to with this directive, "all operators have to take all necessary measures to prevent any major accidents and to have available sufficient physical, human and financial resources to limit the consequences when they do occur." They must obtain a license from an independent authority and must to prepare a proper emergency response plan, to respond to any major hazard. Also, they have to inform the public, before the exploration, about the possible effects of any planned offshore operations [9].

According to this directive, Romania has adopted the Law no. 165/2016 on offshore oil operations safety, which establishes the minimum requirements for the prevention of the major accidents and limitation of the consequences of such accidents involving oil operations in the Black Sea areas under Romanian jurisdiction [10].

The authority responsible for all issues relating to the prevention and response to the major accidents in offshore operations is the European Union Offshore Oil and Gas Authorities Group (EUOAG). It is a forum for the exchange of information and expertise between National Authorities, Third Countries, Industrial Associations, the European Commission and other stakeholders. The EUOAG has the role to promote and facilitate the application of the best practices and highest safety standards in offshore oil and gas operations worldwide [11].

In Romania, the authority responsible for all these is the Regulatory Competent Authority for offshore oil operation at the Black Sea (ACROPO) [12].

\section{The minimum requirements for the safety and health of workers in the offshore industry}

The Directive 92/91/EEC, which is the eleventh individual Directive within the meaning of Article 16 (1) of Directive 89/391/EEC, amended by Directive 2007/30/EC, establishes the minimum requirements for the protection of the worker's safety and health in the mineral-extracting industries through drilling [13].

The Romanian legislative act according to this directive is Decision no. 1050/2006 on minimum requirements for the safety and health of workers in the drilling industry. This act contains common minimum requirements applicable to the ground and offshore drilling sectors; minimum requirements applicable to the ground drilling sector; special minimum requirements applicable to offshore drilling sector. Under this act, workers must be provided with the necessary information, training and professional development necessary to ensure their safety and health. The employer must ensure that workers receive instructions in their terms so that they do not compromise their safety and health or that of other workers [14].

If the health and safety document so provides, a work permit system should be introduced for the execution of hazardous works and for the execution of works that are not normally dangerous but which, in interaction with other activities, may generate serious hazards. Work permits must be issued before the work begins by the person designated for that purpose and must contain the conditions to be met and the measures to be taken before, during and after work.

For each workplace, written instructions should be developed, including rules to be followed to ensure the safety and health of workers and the safe use of the machinery. These instructions must include information on the use of intervention equipment, as well as on the measures to be taken at or near the workplace in case of emergency. 


\section{The main requirements related to learning needs and competencies}

According to the Law on safety and health at work no. $319 / 2006$, the employers shall designate one or more workers to carry out the activities related to the protection and prevention of the occupational risks, named designated workers, or they shall enlist external services. The training levels required are at average level and highlevel, certified by a diploma of studies and a certificates for the graduation of the courses. The representatives of workers with specific responsibilities in the field of the safety and health must follow a basic training program in the field of health and safety at work of at least 40 hours.

The training courses and programs in the field of safety and health at work are performed by authorized vocational training providers, according to the provisions of the Government Ordinance no. 129/2000 regarding the vocational training of adults, republished, with subsequent amendments and completions [15]. The contents of the OSH training courses corresponding to each training level are specified within Annex 6 of the Methodological Norms for the enforcement of the law no. $319 / 2006$.

Through the Decision no 567/2015, the Romanian Government updated the national qualifications framework with eight levels based on labor market requirements and offered training, in accordance between it and the European benchmark, thus linking national qualifications systems in Europe [16].

According to International Standard Classification of Occupation (ISCO 08), Classification of Occupations in Romania (COR) contain the occupations specific to the field of occupational safety and health: at average level: 325721 - OSH Technician; 325723 - OSH Inspector; 325724 - OSH Coordinator; at high level: 226303 - OSH Coordinator; 242304 - OSH Expert [17].

In Romania, there are no special occupations and explicit requirements for OSH specialists in the offshore industry.

\section{Romanian Higher Education relevant to offshore industry}

In Romania, some universities, located in the Black Sea area or areas with important oil and gas fields, offer programs of studies relevant to the offshore industry.

CONSTANTA MARITIME UNIVERSITY is a public institution of higher education and research that offers the next specializations, degrees or certificates, related to the offshore industry:

- Bachelor of Science Degree in Navigation and Naval Transport; Navigation and Waterborne Transport; Naval Electromechanics;

- Master Degree in Offshore Oil and Gas Technology and Management; Advanced Engineering in the Offshore Oil and Gas Industry;

- International Maritime Organization (IMO) Certificates of competency for aspiring marine officers (cadets) [18].

"MIRCEA CEL BATRAN" NAVAL ACADEMY is a polytechnic higher education establishment, which provides education and training programs both for military cadets/midshipmen/officers of the Romanian Navy/Coast Guard, but also for civilian engineering specialists for the Merchant Marine sector and provides: - Bachelor Degree in Naval Electromechanics; Electrical Engineering; Navigation and Maritime and River Transports; Naval and Port Engineering and Management;

- Master Degree in Naval Electromechanical Systems; Nautical Sciences; Naval and Port Engineering and Management; Management of Logistic Systems.

It has, in its structure: Damage Control Training Center (firefighting, waterflood simulation); Seamanship and Sailing Training Center [19].

OVIDIUS UNIVERSITY OF CONSTANTA is a public higher education institution that offers the next specialization related to offshore industry:

- Bachelor Degree in Naval equipment and installation; Port and marine installation and equipment;

- Master degree in Engineering of advanced naval systems and equipment [20].

PETROLEUM - GAS UNIVERSITY OF PLOIEŞTI, through the Faculty of Oil and Gas Engineering, is the only faculty in Romania that prepares specialists in the field of oil and gas exploration. It offers the next specializations, related to the offshore industry:

- Bachelor of Science Degree in Oil \& Gas Engineering; Transportation, storage and distribution of hydrocarbons; - Master Degree in Drilling of wells; Oil extraction; Deposit engineering; Technology of transport, storage and distribution of hydrocarbons; Management in the oil industry; Petroleum engineering;

- Doctoral studies in Mine, oil and gas [21].

\section{Safety and health training courses for the workers from the offshore industry}

Offshore Petroleum Industry Training Organization, commonly known as OPITO, is responsible for the standards in the oil and gas industry, particularly in emergency response and training. The standards set by OPITO are produced and agreed by related groups, and those that passed such standards are recognized worldwide. There are more than 205 approved training providers across the globe, of which two in Romania: Romanian Maritime Training Centre (CERONAV) and Regional Air Services Tuzla [22].

International Minimum Industry Safety Training (IMIST) is an OPITO standard that supports the global oil and gas industry to meet the safety targets. The IMIST standard ensures that the workers have the necessary safety awareness and training to reduce the risks and the number of incidents [23].

CERONAV, with an experience of more than 40 years in vocational education and training, obtained accreditation from OPITO in October 2012 for three training courses: BOSIET - Basic Offshore Safety Induction and Emergency Training; HUET - Helicopter Underwater Escape Training; FOET - Further Offshore Emergency Training, in 2016 gained accreditation for 
H2S and Escape Chute courses and in April 2018, for the Digital Course - BOSIET [24].

SEA SURVIVAL SCHOOL, Tuzla International Airport, is the first training provider from Eastern Europe, in response to the emergency situations, in the offshore industry and the air transportation. The training centre was opened for operations in 2010, and currently ensures training courses BOSIET; HUET; FOET; CA-EBS Initial Deployment Training (CA-EBS); Basic H2S Training; International Minimum Industry Safety Training (IMIST), an online course offered on behalf of ATLAS highly recommended for all inexperienced employees in the oil and gas industry [25].

GSP TRAINING CENTER offers the next offshore training courses: BOSIET and HUET (in partnership with CERONAV); Start-Up Your Career in Offshore; Basic Offshore Safety Induction; IADC (International Association of Drilling Contractors) Rig Pass; Advanced Safety Management Training; HSE (health, safety and environment) on-site; H2S Awareness Including Breathing Apparatus; Working at Height - Rescue and Self-Rescue Training; Confined Space - Working and Rescue Training [26].

\section{Conclusion}

The Romanian Occupational Safety and Health system might be characterized by a comprehensive legislative framework that fully transposed the EU legislation in the area and an adequate institutional framework aligned to the Community requirements in the field. According to the Romanian law in force, there are the minimum training requirements in the field of occupational safety and health corresponding to the average level and higher level OSH training. According to International Standard Classification of Occupation (ISCO 08), Classification of Occupations in Romania (COR) contain the occupations specific to the field of occupational safety and health, necessary to carry out prevention and protection activities. In Romania, there are no special occupations and explicit requirements for OSH specialists in the offshore industry. Authorized vocational training providers perform the training courses and programs in the field of the occupational safety and health. In Romania, there are some training centers, which offer theoretical and practical courses for those graduates or professionals who wish to pursue a professional career in the offshore industry, with specialization on H\&S offshore, like BOSIET, HUET, FOET, H2S, ESCAPE CHUTE, IMIST, and others. Also, there are some Higher Education Institutions in Romania, which provides diplomas (Bachelor Degree, Master Degree, Ph.D. Degree), courses or training related to the offshore industry.

This paper was supported by the project Erasmus+ 2017-1CY01-KA202-026782 - "Development of a VET Training Program to upgrade the Skills on Health and Safety Risks for Offshore Construction Workers".

\section{References}

1. sgg.gov.ro - General Secretariat of the Romanian Government

2. Law no 319 of 14 July 2006 on Safety and Health of Workers at Work, Romanian Official Gazette, Part I no. 646 of 26.07 .2006

3. Government Decision no. 1425 of 11 October 2006, Methodological Norms for the enforcement of the Law no. 319 on Safety and Health at Work, Romanian Official Gazette, Part I no. 882 of 30.10 .2006

4. www.mmuncii.ro - Ministry of Labor and Social Justice

5. www.ms.ro - Ministry of Health

6. https://www.inspectiamuncii.ro - Labor Inspection

7. http://www.inpm.ro - National Research and Development Institute of Occupational Safety

8. http://site.anc.edu.ro - National Qualifications Authority

9. Directive 2013/30/EU of the European Parliament and of the Council of 12 June 2013 on safety of offshore oil and gas operations and amending Directive 2004/35/EC, OJ L 178 of 28.06 .2013

10. Law no. $165 / 2016$ on offshore oil operations safety, Romanian Official Gazette, Part I no. 572 of 28.07.2016

11. https://euoag.jrc.ec.europa.eu/ - European Union Offshore Oil and Gas Authorities Group (EUOAG)

12. http://acropo.gov.ro/web/ - Regulatory Competent Authority for offshore oil operation at the Black Sea (ACROPO)

13. Directive 92/91/EEC, which is the eleventh individual Directive within the meaning of Article 16 (1) of Directive 89/391/EEC, OJ L 348, 28.11.1992, p. 9

14. Government Decision no. $1050 / 2006$ on minimum requirements for the safety and health of workers in the drilling industry, Romanian Official Gazette, Part I no. 737 of 29.08 .2006

15. Government Ordinance no. 129/2000 regarding the vocational training of adults, republished, Romanian Official Gazette, Part I no. 110 of 13.02.2014

16. Government Decision no. 567/2015 on the national qualifications framework, Romanian Official Gazette, Part I no. 572 of 30.07 .2015

17. http://data.gov.ro/dataset/clasificarea-ocupatiilordin-romania - Classification of Occupations in Romania 18. https://cmu-edu.eu/en - Constanta Maritime University

19. https://www.anmb.ro - "Mircea cel Bătrân” Naval Academy

20. www.univ-ovidius.ro - Ovidius University of Constanta

21. https://www.upg-ploiesti.ro - Petroleum - Gas University of Ploiesti

22. https://www.opito.com - Offshore Petroleum Industry Training Organization

23. https://www.imist-online.com - International Minimum Industry Safety Training

24. https://www.ceronav.ro - CERONAV, Romanian Maritime Training Centre

25. http://www.sea-survival.ro - Sea Survival School

26. http://gsptrainingcenter.com - GSP Training Center 